L'Adaptation. Par Prof. L. Cuénot. (Encyclopédie scientifique: Bibliothèque de biologie générale.) Pp. 420. (Paris: Gaston Doin, 1925.) 20 francs.

Prof. CúnNot has done biologists a service in writing this book. It contains treasures of knowledge, which have been treated with great skill and acumen.

Especially valuable, perhaps, are the sections distinguishing the different types of adaptation (necessary and sufficient adaptation, statistical adaptation, etc.) ; those dealing with the important but limited rôle of what is usually called pre-adaptation; the assemblage of interesting facts on co-adaptation; the section on adaptations which are analysable into individual modifications and germinally-determined characters both acting in the same sense; and that on the reason for the rarity or absence of primitive and intermediate types.

Prof. Cuénot is perhaps less good on the bearing of mutations on the problem. It is difficult to see why he regards natural selection as only weeding out mutations which depart from the type: Why should not the neo-Darwinian scheme work with mutations as its raw material? Also, in his discussion of orthogenesis and co-adaptations, he often forgets, or seems to forget, the important fact that an organism's environment is largely composed of other organisms, and that therefore we should expect to find an improvement in one organism bringing out improvements in another, as improvements in naval guns brought out improvements in armour plate and vice versa. This principle will at least help to account for many (though probably not all) of the simultaneous, slow, "orthogenetic' lines seen in palæontology. He could have accounted for some other orthogenetic phenomena by reference to the mechanisms of heterogonic growth (as summarised by Champy in his "Sexualité et Hormones").

Prof. Cuénot is sceptical as to the value of any of the existing explanations of adaptation, whether by Lamarckian means, by slow selection, by large mutation, or by predetermined orthogenesis. However, whether we share his scepticism or not, he has here provided considerable food for thought on one of the central problems of biology.

Penrose's Annual : the Process Year Book and Review of the Graphic Arts. Edited by William Gamble. Vol. 28, r926. Pp. xvi + $146+70+57$ plates. (London: Percy Lund, Humphries and Co., Ltd., I926.) $8 s$. net.

THE editor, in his usual review of process work, says that he regretfully confesses that the year.1925, the end of a quarter century, shows " no new process, nor change of method, which is of outstanding importance; nothing, in fact, that could be regarded as a milestone of progress passed in the onward march of our art and craft." Much is being done, but it is in continuance of work started in previous years, especially since the War, and it may be expected to bear fruit in the immediate years to come. The editor then describes the remarkable progress that has been made during the quarter of a century just completed, which includes the introduction of the offset method and rotary photogravure. Colour gravure, based on three-colour principles, is making great headway, and an example is given of a flower study reproduced by this process, and also by a letterpress method from four blocks, so that the two results can be compared. Collotype is still printed on slow-running flat-bed machines which are turning out excellent work, and "it hardly seems likely that this practice will ever be altered." The progress of the various methods of replacing the ordinary type setting of text by photographic methods are passed in review, but it seems that none have yet convinced the printing trade of the advantages of these inventions over existing methods.

The text consists of 34 articles by experts, who give experiences or data of value. The curious chemical equation at page I 29 shows that practical men should be content to leave theory to those that understand it. The fifth of the series of "The Work of the Private Presses" is by Mr. Chas. T. Jacobi on the Eragny Press, I894-I9I4, and is illustrated with specimens. The numerous plates may be considered as showing the best that can be done to-day by perhaps every process that is in use.

A System of Physical Chemistry. By Prof. William C. McC. Lewis. (Text-Books of Physical Chemistry.) In 3 vols. Vol. 2: Thermodynamics. Fourth edition. Pp. viii +489 . (London : Longmans, Green and Co., r925.) I $5 s$. net.

The third edition of Vol. 2 of Lewis's "Physical Chemistry" appeared in 1920, and included 445 pages of text. The fourth edition has been increased to $48 \mathrm{I}$ pages, mainly by the inclusion of half a chapter on "The Activity Theory of Evolutions" and half a chapter on "The Milner-Debye Theory of Strong Electrolytes." In accordance with the author's policy of quoting extensively from. original sources, the latter section is taken from a paper by A. A. Noyes which appeared in the Journal of the American Chemical Society in 1924 .

British Birds. Written and Illustrated by Archibald Thorburn. New edition. In 4 vols. Vol. 2. Pp. ix $+\mathrm{r}_{30}+4^{8}$ plates. (London: Longmans, Green and Co., 1925.) I6s. net.

THE first volume of the new edition of Mr. Thorburn's "British Birds" has already been noticed in these columns (September r2, p. 390); the second of the four has now appeared. The coloured plates are again very beautiful, but the amount of space given to rarities, in text and picture, continues to keep the treatment of more important birds within rather narrow limits. One is glad to note, however, the figuring of so many as three plumage-phases of the great spotted woodpecker, and that the immature plumage of the gannet is also shown.

\section{Laboratory Manual of Elementary Colloid Chemistry.} By Emil Hatschek. Second edition. Pp. I53. $_{53}$ (London: J. and A. Churchill, 1925.) 7s. 6d. net.

THE second edition of Hatschek's " Laboratory Manual of Elementary Colloid Chemistry" contains new chapters on "Oxide and Hydroxide Sols" and on "Non-aqueous Emulsoid Sols and Gels." Methods for determining the coagulation velocity and for demonstrating the variation of viscosity with rate of shear have also been included. 